\title{
Study of Utilization Under Sea-water Hydrostatic Pressure as Hydro Power Generation
}

\author{
Dan Mugisidi ${ }^{1 *}$, and Oktarina Heriyani ${ }^{2}$ \\ ${ }^{1}$ Department of Mechanical Engineering, Faculty of Engineering, Universitas Muhammadiyah Prof. DR. HAMKA, \\ Jakarta - Indonesia \\ ${ }^{2}$ Department of Electrical Engineering, Faculty of Engineering, Universitas Muhammadiyah Prof. DR. HAMKA, \\ Jakarta - Indonesia
}

\begin{abstract}
Harvesting energy from hydrostatic pressures in the ocean depth involves many variables that create complex situations. Variables such as pressure, temperature, water flow, and even fish are examples of variables that must be taken into account. In this study, the variables used to estimate power generation are pressure and depth. The purpose of this research is to get the picture of power potential that can be obtained by utilizing hydrostatic pressure under the sea. The study is base on literature from previous research and calculation. The generator is assume coupled with reverse osmosis equiptment so that the output is fresh water and electricity. The calculation base on information of population in Pramuka island that required $288 \mathrm{~m}^{3} /$ day. The results show that the power generated is $16 \%$ of the available power potential and save electricity cost of water distribution $913 \mathrm{Rp} / \mathrm{m}^{3}$ or reduced $46 \%$.
\end{abstract}

Keywords: pressure, under water, hydrostatic, energy, sea water

\section{Introduction}

«When the well is dry, we know the worth of water » (Benjamin Franklin)

Water is an indispensable necessity for living things and has become a global problem. Humans, animals and plants need water to survive. As population increased from about 5.3 billion in 1992 to about 7.0 billion in 2012, water demand increase dramatically (1). Water scarcity is not longer a fiction since the water demand has triple in 50 years, globally (2). 1 of 4 children will live in rare area of water (3). It will also threaten Indonesia. Indonesia which is a country consisting of thousands of islands and surrounded by vast ocean, therefore making sea water as raw water for fresh water very reasonable. Unfortunetely, the seawater contain the large amounts of salt such as Fluoride, hardness (CaCo3), Chloride, Sodium, Sulfate, and Potassium Permanganate (KMnO4) (4). One of the most ways to remove salt content in sea water is reverse osmosis (RO). One of the variables that greatly affect RO performance is water feed pressure which has range between 50 bar -90 bar (5). High feed water pressure and flow rate require large pump energy, so some efforts are made to reduce energy costs by utilizing renewable energy. One of them is hydrostatic pressure. Therefore Hydrostatic pressure reduces the electricity consumption for the reverse osmosis process from 10 (kwh / m3) to 2.98 (kwh / m3) (6). Usage of hydrostatic pressure as energy source has efficiency $80 \%$ in desalination process with RO (7). In this study, fresh water generated by RO is pumped to the surface. To reduce energy costs, underwater waterwheel is positioned before RO. Pressurized sea water will enter and push the mill into rotation before entering into RO. The energy produced by the waterwheel will be used to reduce the energy of freshwater pumps. This study focused on the estimated energy calculations obtained from the waterwheel and the cost to be reduced.

\section{System Design}

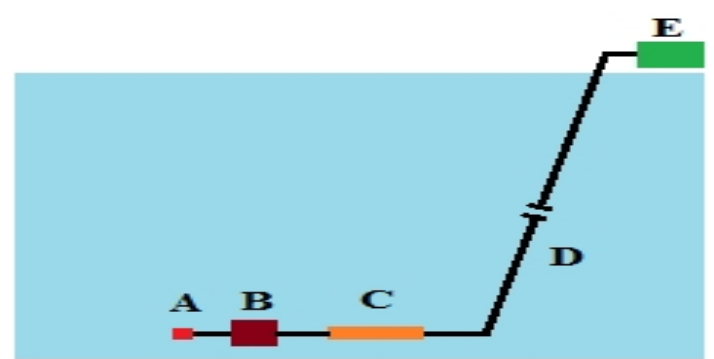

Figure 1 Scheme of Underwater turbine with submarine RO. $A=$ Coarse Filter, $B=$ Underwater Turbine, $C=R O$ submarine unit, $\mathrm{D}=$ piping, $\mathrm{E}=$ Fresh water pump

* Corresponding author: dan.mugisidi@uhamka.ac.id 


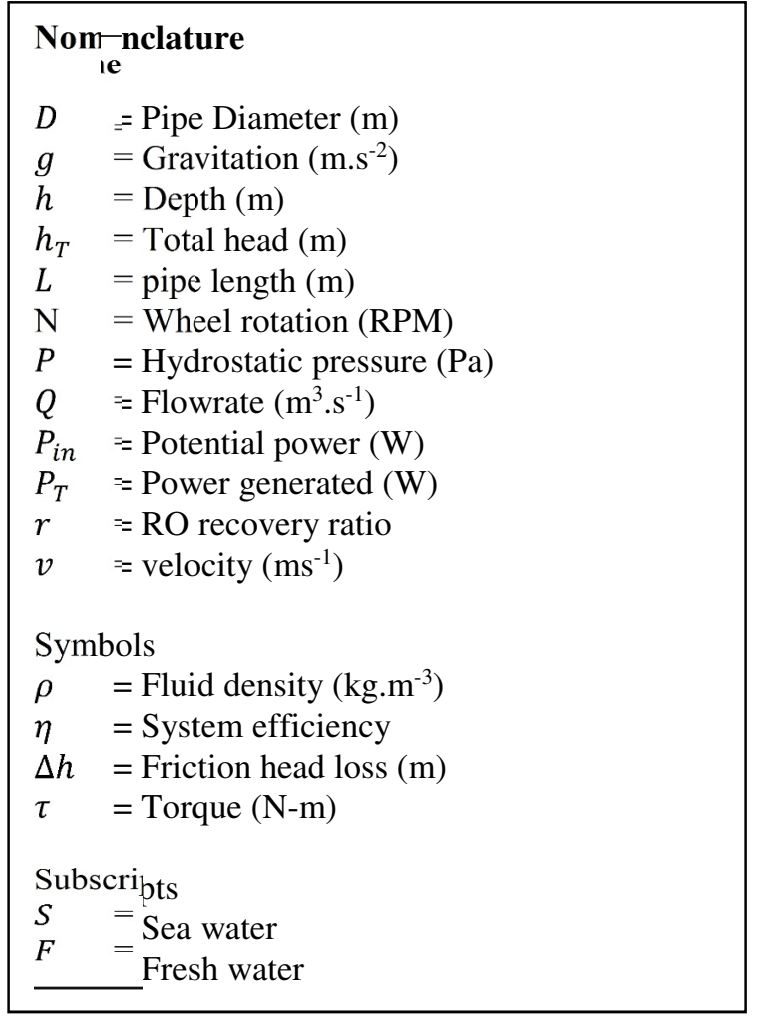

As shown in Figure 1, Underwater turbine is situated before RO desalination unit. Underwater turbine is situated before the RO unit. Since RO operational pressure requires a certain amount of pressure, the output pressure of underwater waterwheel should not be less than RO operational pressure. Hydrostatic pressure is calculated with this equation,

$$
P=\rho_{s} \cdot g \cdot h
$$

$\rho_{S}$ is fluid denstity of sea water. In calculation the fluid density is $1,025\left(\mathrm{~kg} \cdot \mathrm{m}^{-3}\right)$. Gravitational acceleration is $9.81\left(\mathrm{~m} . \mathrm{s}^{-2}\right)$. The potential power due to the hydrostatic pressure is

$P_{\text {in }}=Q \cdot \rho_{s} \cdot g \cdot h_{T}$

The power generated is calculated base on rotation and torque of the wheel.

$P_{T}=\frac{2 \cdot \pi \cdot N \cdot \tau}{60}$

Rotation of the wheel obtained from velocity of sea water inside the wheel. Torque is calculated from force of water flow multiply by radius of the wheel. $v=\frac{\pi \cdot D_{W} \cdot N}{60}$

$T=F \cdot r$

Force $(F)$ is calculated from the pressure difference between the hydrostatic pressure and the pressure required by the RO operational pressure $\Delta P$.

$F=\Delta P \cdot A$

Where $\mathrm{A}$ is area of the wheel blade.

to obtain an appropriate operational pressure of 70 bar, using equation (1), then the required depth is $696.15 \mathrm{~m}$. assuming the hydrostatic pressure is 1.5 times RO operational pressure then the required depth is $1,044.23(\mathrm{~m})$. So that, $\Delta P$ is 35 bar or 3,500,000 Pascal. To calculate flow rate of fresh water, Pramuka island is used as a base line. With population of 2,000 people (8) and an average water usage of 144 liters per person per day then the water requirement is $288,000(1 / \mathrm{d})$ or $12\left(\mathrm{~m}^{3} / \mathrm{h}\right)$. in second the flow rate is $0.00333\left(\mathrm{~m}^{3} / \mathrm{s}\right)$, this is expected fresh water from RO unit. Ratio recovery of fresh water is 0.25 (7) then the flow rate of turbine is 0.00444 . The potential power at the depth is $47(\mathrm{KW})$ but since $\Delta P$ is $3,500,000(\mathrm{~Pa})$ then the potential power consider only $15.56(\mathrm{KW})$. Efektif Diameter of turbine is assume $1.5(\mathrm{~m})$ so the radius is $0.75(\mathrm{~m})$. The effective area of the turbine blade is $0.02\left(\mathrm{~m}^{2}\right)$ so that the force obtained is 70,000 Newton and the torque is $52,500(\mathrm{~N}-\mathrm{m})$

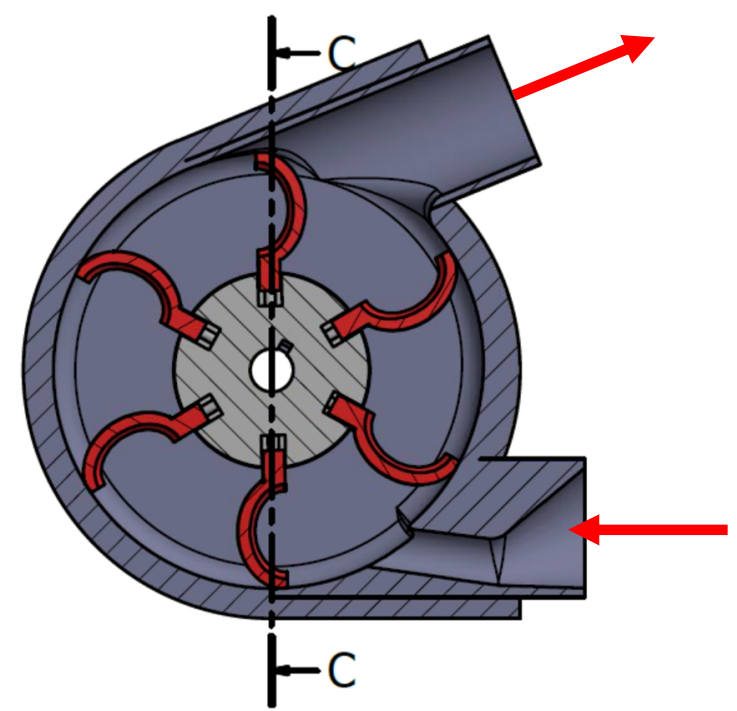

Figure 2. Underwater turbine

Velocity of the blade turbine is assume same as velocity of water flow inside the turbine and calculated with continuity formulation, then $v$ is 0.22 $\left(\mathrm{m} . \mathrm{s}^{-1}\right)$ and rotation is $2.83(\mathrm{r} / \mathrm{m})$. The efficiency of the turbin is assume $80 \%$ then the power output of the the turbine is $12.44 .33(\mathrm{KW})$. The total efficiency of the generator, including the mechanical connection and the power network is considered $60 \%$ so that the power generated by the generator is $7.47(\mathrm{KW})$. Total efficiency of system is about $16 \%$. In this study, the electricity from underwater turbine generator is combine with electricity from State electricity company (PLN) and energize fresh water pump. So that the electricity usage of PLN can be reduced.

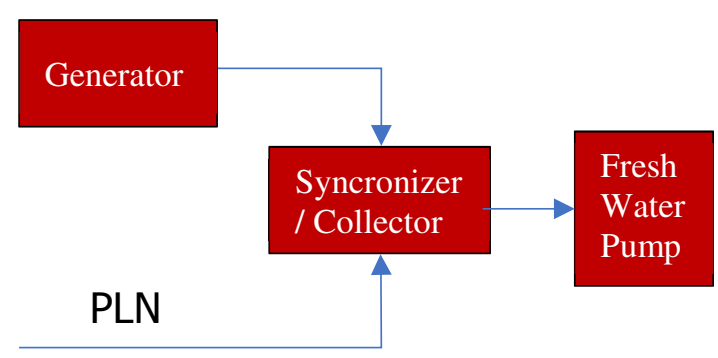

Figure 3. Electricity schema of underwater turbine 
Since fresh water coming out of $\mathrm{RO}$ has greater pressure then it will rise to the surface of the ocean to create a pressure balance with its environment. Friction coefficient on laminar flow is 0.012 so the friction head loss is $0.197(\mathrm{~m})$. Therefore the total head of the freshwater pump is set at 500 meters to handle the suction, discharge and friction head. So the power required by fresh water pump is $16.35(\mathrm{KW})$. If the cost of electricity is $1.467 \mathrm{Rp} / \mathrm{KWh}$, then the cost required to pump fresh water is $2000 \mathrm{Rp} / \mathrm{M} 3$. Utilization of hydrostatic pressure to generate electricity can save $913 \mathrm{Rp} / \mathrm{m} 3$ or decrease by $46 \%$.

\section{CONCLUSION}

The power generated using energy derived from hydrostatic pressure provides a financial advantage. Based on the calculation, the power generated reaches $46 \%$ of fresh water pump requirement. This can reduce the freshwater production cost to become more economical. Since the electricity consumption is reduced, this study will also give contribution for developing lowcarbon society. However, further research on environmental impacts is needed.

\section{Reference}

1. UNEP. UN-Water Status Report on The Application of Integrated Approaches to Water Resources Management. United Nations Environment Programme. 2012. 1-119 p.

2. Vigotti R, Hoffman A. The water scarcity and Water Scurity: po;itical and Social implications. In: Technology and Water. Rome: IEA Working Party; 2009.
3. UNICEF: 1 dari 4 Anak akan Tinggal di Daerah Langka Air I Republika Online [Internet]. [cited 2017 Jun 29]. Available from: http://www.republika.co.id/berita/internasional/glo bal/17/03/23/on8xa8384-unicef-1-dari-4-anakakan-tinggal-di-daerah-langka-air

4. Mugisidi D, Heriyani O. Sea Water Characterization at Ujung Kulon Coastal Depth as Raw Water Source for Desalination and Potential Energy. In: The 2nd International Conference on Energy, Environmental and Information System (ICENIS 2017) [Internet]. 2018 [cited 2018 Apr 25]. Available from: https://www.e3s-

conferences.org/articles/e3sconf/pdf/2018/06/e3sco nf_icenis2018_02005.pdf

5. Sassi KM, Mujtaba IM. Effective design of reverse osmosis based desalination process considering wide range of salinity and seawater temperature. DES [Internet]. 2012 [cited 2018 Jul 14];306:8-16. Available from: http://dx.doi.org/10.1016/j.desal.2012.08.007

6. Charcosset C, Falconet C, Combe M. Hydrostatic pressure plants for desalination via reverse osmosis. Renew Energy. 2009;34(12):2878-82.

7. Reali M, de Gerloni M, Sampaolo A. Submarine and underground reverse osmosis schemes for energyefficient seawater desalination. Desalination [Internet]. 1997 Jun [cited 2017 Jun 30];109(3):269-75. Available from: http://linkinghub.elsevier.com/retrieve/pii/S001191 6497000738

8. Pulau Pramuka - Wikipedia bahasa Indonesia, ensiklopedia bebas [Internet]. [cited 2018 Jul 15]. Available

from: https://id.wikipedia.org/wiki/Pulau_Pramuka\#Dem ografi 